\title{
Reply to the forum commentaries on the article, "The new Chinese working class in struggle"
}

\section{Ngai Pun ${ }^{1}$}

Published online: 3 August 2020

(C) Springer Nature B.V. 2020

I am particularly grateful to Winnie Lem and Anthony Marcus for organizing the "Workers of the World!" forum in Dialectical Anthropology and inviting me to engage in this meaningful event. Against the defeatist narrative that frames the working class movement as a "historical fact" and the attacks from some post-Marxist and post-modernist theories that conceptualize "class" as a political project or a unit of empirical analysis, the organization of this forum is not only timely but also a brave and risky act. I am honored to join this intellectually engaging and politically motivated forum that seeks to revive the politics of class in the Global North, while also learning from the divergent experiences in the Global South, which demonstrates that rather than being obsolete, the politics of the class is global.

I am also thankful for the four commentaries provided by Rebecca E. Karl, Andrea E. Pia, Charlotte Bruckermann, and Simeng Wang whose critiques, comments, and suggestions have broadened my understanding of the new trends in the Chinese workers' struggles, the rich historical experiences of the worker-student alliances in Italy and France, and the development of theories regarding class and workers' subjectivity in other contexts. They have also enhanced my insight into the relationship between production, social reproduction, and social resistance. I have benefited from these discussions and comments, and I hope that my response can further enrich the debates, particularly in terms of how we think about the working class not only in China but also worldwide.

Among the four commentaries, Rebecca E. Karl, while very supportive of my work, raised the mostly sharp critique: "it is not clear to me that we can talk meaningfully about a suprahistorical subject named 'workers [of the world]' other than as an objective feature of a capitalist system, whose global logic continually is produced through and intended to produce disunity" (Karl 2019). In the following, I will try my best to address this critique as this critique is also shared by other commentators. Simeng Wang also kindly alerts me to move beyond the horizon of China as capital has rapidly flowed into other developing societies such as South Asia or Africa, and labor politics in China has to connect with other alter-globalization movements initiated by other "workers of the world" (Wang 2020).

Ngai Pun

npun@hku.hk

1 Sociology, University of Hong Kong, Line 1: 907, Jockey Club Tower, Hong Kong, Hong Kong 
Many people who are sympathetic to my work have, however, expressed concern that I have not sufficiently captured the complexity of class and the multiplicity of resistant subjects; thus, I am not able to advance the theoretical debate from the first book, Made in China: Women Factory Workers in a Global Workplace (2005), or even retreat to an orthodox understanding of the Marxist concept of class. I must admit that I am aware of the friendly reminders that, as a macro theory, Marxist class theory's explanatory power runs counter to both the historical communist revolutions in the Global South and the varieties of capitalism around the world which are increasingly fragmented as lived experiences. At the same time, I am equally aware of the repeated articulation of "the precarity of the working class" in academia; its fragmentation and divisiveness reflect the discursive effects of "capitalist realism" which reconfirms a reified story of "no alternative: it is easier to imagine an end to the world than an end to capitalism" (Fisher 2009).

Returning to the Marxist theory of the working class was, for me, less about an intentional rejection of new theories, which are often termed as "a new theory of resistance" or "theory of radical democracy," and more about historical necessity and praxis, shaped by my fieldwork in the special economic zone of Shenzhen, China, and the profound changes that have occurred as a result of global capitalism. Through this fieldwork, I met resistance subjects who, in today's China, are the workers and the students. I regret that I have not engaged with other resistance subjects such as peasants, feminists, environmentalists, and others whose issues of concern have increasingly been incorporated into the global capitalist world dictated by the "visible hand" of the authoritarian party state. However, my understanding of their struggles has convinced me that the fight for an alternative communist society is the basic and shared ground for all forms of social resistance to be fully developed and enacted. Fighting for the end of capitalism is simply the beginning of fundamental social change. It is part of an ongoing revolution, wherein resistance subjects will continue the pursuit of their emancipation and transformation.

However, the workers and the students I encountered, unlike the labor studies academics who have repeatedly reminded me about the precariousness of the working subjects and their resulting lack of class solidarity, anxiously asked me to stand firmly with them while they struggled. They also demanded that I use my "privileged position" to communicate their experience as a proletariat who are deeply in need of solidarity and unity. The double denunciation of Marxism and class in China through the historical amnesia of Marxism as a lived revolutionary tradition in the twentieth century, and the appropriation of Marxism by the state as an official ideology, purposefully stripped the theory of its revolutionary roots and analytical power (Pun and Lin 2020). This has led to working class subjects being invisible in both progressive intellectual circles and mass media, despite a dramatic increase in strike actions and protests in response to the structural changes caused by the fact that China was, and will continue to, the "world's shop" in the international division of labor. Making the working class invisible, silencing their voices and demands no matter how defiant they are, and constructing them as the "outcasts" of postmodernist theories or new social movement theories are the concomitant "achievement" of the "radical or plural democracy theory" which serves as the rhetorical foundations of contemporary society (Laclau 2014).

The rhetorical foundations are not the materialist foundations of the global capitalist society. In forging the resistance politics and solidarity against the materialist foundations of the global capitalist society, Charlotte Bruckermann raised the question that "what do second-generation nongmingong, literally peasant-workers, have in common with the students with high level of education and training?" (Bruckermann 2020) For many of the workers I have known in China, the logic of capital is, for sure, the logic of 
"divide and rule" over the working class, and among these working-class subjects, there is an overt hierarchy and division generated by the global capital machine whose sole goal is valorization and monopoly. To the students, the logic of capitalism is the logic of elitism and egoism embedded in the mode of capitalist life which inevitably embodies individualization, competition, and alienation, and at worst, a logic of winners takes all. The logic of capital and the logic of capitalism doubly create a historical conditioning for the possible combination of both workers and students in struggle, with the students increasingly recognized themselves as part of the working class facing the same global capitalist society. As a result of the logic of capital and the logic of capitalism, and the historical conditioning of my subject position - a labor scholar engaging in the Chinese labor movement-I found myself having no choice but to unreservedly embrace these ontological and historical subjects in struggle, namely, "workers of the world"!

Andrea E. Pia insightfully connects my research and political projects to the Italian workers' movements of the 1960s and 1970s, which was particularly interesting and valuable (Pia 2019). Reflecting on the failure of the Italian workers' movements led theorists, such as Antoni Negri and Michael Hardt, to develop a theory of workerism that called for a new subject of multitude and radical forms of resistance to move beyond the tradition of Marxist class theory which was deemed to be inadequate and insufficient in terms of understanding contemporary labor subjects. In response to Chinese students' engagement in the support of Foxconn workers since 2010, we invited several Italian scholars, who were then student activists and either directly participated in, or supported, the Italian labor movement, including Ferruccio Gambino, Devi Saccetto, Alexandro Russo, and Sandro Mezzadra to come to China or Hong Kong. These scholars ran workshops to share their rich and painful experiences of the movement with the Chinese and student activists.

In November 2014, I was invited by Wang Hui to serve as the commentator to Antoni Negri's talk, "Metropolis as the Post-industrial Factory" at Tsinghua University. Before taking up this role, I discussed with a group of Chinese leftwing students and together we constructed several questions for me to ask him which reflected our queries and concerns about the new theories developed after the defeat of the Italian worker-student alliance movement. (Hardt and Negri 2004; Hardt and Negri 2017) I shared a series of questions to Antoni Negri here:

The year 1979 marked the transition to neoliberalism in the West and the beginning of the end of the welfare state; it was also the most repressive year for the Italian autonomous labor movement. I would like to ask about the reason for the defeat of the Italian labor movement: was it because of the lack of a new theory of political subjectivity (your subsequent contribution), the absence of progressive forms of organizing (your constant criticism of Marxist-Leninist party form), or the capitalist assault in response to the growing student-worker alliance of the 1970s where, given the imbalance of class forces, the movement had to fail? If it is the latter, then it is a question of balancing class forces, not a question of new class subjectivities or forms of organization.

I am particularly interested in the Italian workers' autonomous movement because of the participation of intellectuals and students. I have also seen debate around the time, including a critique of your work, where you argued that the notion of "mass workers" is 
irrelevant and that we have to retreat from the sphere of production into the sphere of life, at a time when student and worker leaders were being arrested in the factories, and the labor movement faced severe repression. Since then, there has not been any revival of the student and worker movement. I would like to ask how you respond to these comments.

Your contribution to the theorization of resistance, from "mass worker", "socialized worker" to "multitude", is widely known. In particular, "multitude" responds to the new global capitalist modality, and the inversion of society and factory in network societies: today's factory is the metropolis, and what is produced are not only commodities but immaterial labor and worker subjectivity - in other words, biopolitics. This theory is illuminating because the boundary between the factory and society is abolished, and the resistance subjects are widened in scope. But I would like to tell an unfunny joke: if Foxconn workers in China agree with your idea that the worlds inside and outside of the factory are identical, perhaps more of them will commit suicide. What I mean is that in the lived experience of workers, these two worlds are different. Although both share the same conditions of alienation, only through expecting a life outside of the workplace, could the life on the assembly line become so intolerable that it must be resisted? The world outside of the factory compensates for the alienation inside the factory, and it is a driving force for resistance.

I do not mean to refute your concepts of the multitude and the common. The four forms of new resistance subjects in your book Declaration are instructive. But I would like to ask: under capitalist relations of production, how do we confront the real subsumption of capital? In your theorization, subsumption is ubiquitous, from everyday life and emotions to life itself. It is dispersed, fragmented and microscopic. Then what are the conditions of resistance for the multitude? How could the common of the multitude be created in action? When Marx regards commodity as the representative of capitalist production, it is because the commodity embodies the antagonism of the two classes. I do not disagree with your analysis of immaterial production. The question is: where do we locate the contradictions and antagonisms in immaterial production? Could there be any internal or external crisis within the multitude that drives resistance?

Finally, I would like to ask about the dialectical relationship between multitude and class. You state across many books that multitude is a class concept, but for you, class is also subjective without an objective basis. We cannot, therefore, ask: who is our enemy, and who is our friend? If multitude cannot be subject to an objective analysis of class, how do we know who will repress and smear us, and who will unite with us? Without class analysis, we cannot even raise the question of "we" in relation to the common, and we cannot ask the social conditioning for class struggle. As a theory of subjectivity of resistance, there remain ambiguities in the multitude of the metropolis. It has to be developed further to answer the question of "what is to be done". 
Four years later in 2018, Jasic workers and leftwing students joined hand in hand in challenging the factory management and the police in China, and like the Italian workerstudent movement, they were severely suppressed. Workers and students were arrested. The same set of questions I am putting to Antoni Negri now squarely confront us - the asymmetry of class forces is the real issue. Re-naming the workers and students as resistant subjects would not help to enlarge their force, and distracting from a materialist analysis of class is even harmful to the development of labor movements, not to mention replacing concrete forms of organizing with some novel concepts which do not resolve the issues of power and organizational democracy. Direct actions, spontaneous protests, autonomous movements, or more organized forms of labor all have their potential and limitations, and "the form of organizing" itself would not determine the success or failure of the movement; rather, it is shaped by the historical conditioning - under severe repression of the state police and fascist control over national security, "what is to be done," and what forms of organizing are appropriate. This is not a matter of voluntarism or determinism, but a conscious and active praxis that emerges as a result of historical constraints.

The first wave of the worldwide socialist revolutions of the twentieth century has failed. It was encircled and defeated by the expansion of global capitalism as it evolves to a new era of monopoly capitalism and imperialism supported by high technology and new media, as the two commentators said. The second wave of the coming communist revolutions obviously needs a significant amount of new theoretical work to deepen the efficacy of contemporary Marxism. The new theoretical work could inform us about not only the contradictory moments of global capitalism and its resistant subjects but also the reasons for the failures of the first wave. This work could also inform us about the class contradictions inside socialist societies which have not been resolved despite the victories of forceful revolutions, the unresolvable issues between bureaucracy and democracy of the existing socialism and the final betrayal of the socialist party state due to the expansion of contemporary capitalism and its deficiency in resolving the internal crisis. These are at least the most basic and urgent theoretical issues confronting us in China, and we could not agree more that there can be no revolution without a revolutionary theory and deepening class analysis.

\section{References}

Bruckermann, C. 2020. Locating labor and class in contemporary capitalism: historical comparison and spatial analogies in the Chinese politics of place. Dialectical Anthropology. https://doi.org/10.1007/s10624-02009583-5.

Fisher, M. 2009. Capitalist realism: is there no alternative? Oxford: John Hunt Publishing.

Hardt, M., and A. Negri. 2004. Multitude: war and democracy in the age of empire. New York: Penguin Books. Hardt, M., and A. Negri. 2017. Declaration, 2012. Allen: Argo-Navis.

Karl, R.E. 2019. Forum commentary. Dialectical Anthropology. https://doi.org/10.1007/s10624-019-09558-1. Laclau, E. 2014. The rhetorical foundations of society. London: Verso.

Pia, A.E. 2019. We want everything': a commentary to Pun Ngai's 'The new Chinese working class in struggle. Dialectical Anthropology. https://doi.org/10.1007/s10624-019-09567-0.

Pun, N., and K. Lin. 2020. A position paper on the Chinese capitalism and labor struggle project, working paper. Wang, S. 2020. The new Chinese working class in the globalized world: a response to Ngai Pun. Dialectical Anthropology. https://doi.org/10.1007/s10624-020-09587-1.

Publisher's note Springer Nature remains neutral with regard to jurisdictional claims in published maps and institutional affiliations. 